\title{
LEADERSHIP, DISCIPLINE AND MOTIVATION AFFECTING TO THE PERFORMANCE
}

\author{
Marsuhin ${ }^{1}$ \\ Suwignyo Widagdo ${ }^{2}$ \\ Murtadlo 3 \\ Higher Education of Economic Mandala \\ Email : stie-mj@stie-mandala.ac.id
}

\begin{abstract}
This study aims to identify and analyze the influence of leadership, discipline and motivation on the performance, as well as to find out which of the leadership, discipline and motivation are the dominant influence on performance. The subjects in this study are members of Lumajang Police Force Sabhara totaling 63 people.This research uses explanatory research. As independent variables, namely leadership, discipline and motivation, and the dependent variable is the performance. Analysis of the data used are validity and reliability, the classic assumption test, regression analysis, and hypothesis testing.The results showed that the leadership has a significant effect on performance, discipline significant effect on performance, motivation significant effect on the performance and motivation of the dominant influence on performance. The coefficient of determination $\left(\mathrm{R}^{2}\right)$ is equal to 0,795 . This means that $79.50 \%$ of performance can be explained by the leadership, discipline and motivation. While the rest of $20,50 \%$ performance is influenced by other variables not examined in this study.
\end{abstract}

Keywords: leadership, discipline, motivation, performance

\section{INTRODUCTION}

Employee performance problems is very important to attain the objectives of an organization. Human resource policies, especially on improving the performance of employees, there must be an understanding of the factors that affect performance, and subsequently used as a basis for policy making human resource development. Employee performance is essentially determined by the leadership of the leadership itself, the level of discipline and motivation of its employees. This phenomenon is quite relevant because somehow the employee will not be able to work with the maximum if all three factors are unfavorable. According to Hasibuan (2005), the performance is a result of the work of a person in carrying out the tasks assigned to him.

Being a good leader needs to be met the requirements concerning several aspects such as physical, knowledge, skills, attitudes, and certain personality. A leader must successfully manage its resources in an organization, including managing human resources. Management of human resources is that meant it 
should be able to integrate perception or perspective employees and leadership to achieve the purpose, among others, a leader compensation, motivation, direction and coordination. In addition, dreamers must have good leadership to employees. According to Rival (2008), the broad definition of leadership includes influencing the process in determining the organizational objectives, motivate followers to achieve the objective behavior, influence to improve the group and its culture. It also affects the interpretation of the events of his followers, organizing and activities to achieve goals, maintain working relationships and teamwork, gain support and cooperation from people outside the group or organization. Arief's research and Farid (2011) indicates that leadership and significant positive effect on performance, while the research of Yusuf (2010) demonstrates leadership and no significant positive effect on performance.

In addition to requiring leadership figure, an employee at work also requires discipline working to optimize its performance. According to Mangkunagara (2001), discipline as an ideal state in supporting the implementation of tasks according to the rules in order to support the optimization of the work. One condition that discipline can be grown in the working environment is, the division of labor is due to the employee or officer is at the bottom, so that everyone knows to be aware of what duties, how to do it, when the job starts and finishes, such as what the work required and to whom it is accountable for the work. For that discipline must be nourished in order to grow well as order and efficiency. Without good discipline, do not expect there will be realized the ideal figure of the leader or employee as expected by society and institutions. The research of Rahayu and Idrus (2015), proving that discipline emerges positive significant effect on performance, while the research of Hetami (2008) proves that discipline affects both negative and significant effect on performance.

Motivation is often said to be the key to performance. This is because the motivation itself can improve performance. Motivating employees is one of the tasks of a leader. Leaders must not only know how to motivate, but should also be able to invite their employees understand how to motivate the choice to implement it. According to Istijanto (2010), motivation is something that encourages people to take action. Employees also have the motivation to want to work. What encourages employees to work? Certainly not a salary or something worth financially. A number of other motivation is the availability of work, recognition, workplace safety, career and others. The research of Riyadi (2011); and Fitriani, Nasir and Yunus (2015), proves that the motivation on the performance. While Hakim (2011), shows that motivation does not affect the performance.

Lumajang Police Force of Sabhara has a vision, among others, to be a member of the police who are professional, proportionate, moral and uphold the rule of law and human rights. Its mission is to carry out membership in the coaching ranks Lumajang Police, carrying out law enforcement as well as transparency and accountability, implementing cross-sectoral in the context of law enforcement as well as protect and 
serve the community in the field of law enforcement. So as to achieve the vision and mission of Lumajang Police,the Unit of Sabhara has been making various efforts including holding of special training and rewardingthe outstanding members to boost morale for the other members to always compete fairly in improving performance.

The phenomenon which is the case in Lumajang Police Force Sabhara is not all the members have performed as expected, both in quality, quantity and efficiency of their work time in realizing the vision and the mission itself. Decisive leadership is also not enough to improve the performance of this Unit. This can be seen when the new leadership is also alternation of policies that will affect the performance of its members. Some members have shown a great performance concerning with passing leader, but some others are not performing as expected. The discipline involves the few members who still have not been able to finish the job, resulting in piling work, the members who are less timely in completing the work and so forth that indicate nonoptimal performance of members. The discipline of members can be seen from how these members carry out the task daily. There are some members who have demonstrated high discipline both in terms of employment and regulations, but there are also some members of low discipline so that their performance decreases. In addition, the low self-encouragement of the member himself will have an impact on performance. This is also related to the motivation of members which is lacking but there are also members wih highly motivation from both inside and outside the members itselves, so that the performance of members who have less motivation will decrease. These three factors are greater influence on the performance of the unit's members Lumajang Police Sabhara compared with other factors such as commitment, work environment and so forth.

Based on researh gap and a phenomenon that has been described, this study discusses the influence of leadership, discipline and motivation on the performance of the Police Force members Sabhara Lumajang. This study aims to identify and analyze the influence of leadership, discipline, and motivation to performance.

\section{RESEARCH METHOD}

This research was conducted in Lumajang Police. This study is limited to Members Unit Sabhara. Carried out for three months on the Member Lumajang Police Unit Sabhara, research conducted from July to September 2016.

The population in this study were all Members of Lumajang Police Force Sabhara numbered 63 people. The sampling technique used in this study is a sample census means that all members of the population used as a sample. This sample is used for the number of members of the population is relatively small and already meets the criteria in the determination of the study sample. So the sample in this study were all Members of Lumajang Police Force Sabhara numbered 63 people.

The variables analyzed in the study were classified into two types as follows: 
1. Independent Variable: leadership $\left(\mathrm{X}_{1}\right)$, discipline $\left(\mathrm{X}_{2}\right)$ and motivation $\left(\mathrm{X}_{3}\right)$.

2. Dependent variables: performance $\left(\mathrm{Y}_{1}\right)$.

Operational definitions of study variables consisted of indicators of leadership variable in this researchoriented and task-oriented subordinates. Indicators of discipline variables in this study are obedient to the rules of time, obey the rules of the organization, adhere to the rules of conduct in the work, and adhere to other regulations. Indicators of motivation variables in this study are intrinsic and extrinsic motivation. Indicators of performance variables in this study is the quality, quantity, whether or not reliable, and attitude.
Methods of data collection in this research is done by using using questionnaires, interviews, and literature.

Data analysis methods include the validity and reliability, classical assumption (normality test, multicollinearity and heteroscedasticity test), multiple linear regression analysis, and hypothesis testing (t-test, dominant, and the coefficient of determination)

\section{RESULTS ANALYSIS}

The results of the analysis are presented in the following table:

Table 1. Results of Analysis

Coefficients $^{\mathrm{a}}$

\begin{tabular}{|c|c|c|c|c|c|}
\hline \multirow[b]{2}{*}{ Model } & \multicolumn{2}{|c|}{$\begin{array}{l}\text { Unstandardized } \\
\text { Coefficients }\end{array}$} & $\begin{array}{c}\text { Standardi } \\
\text { zed } \\
\text { Coefficien } \\
\text { ts }\end{array}$ & \multirow[b]{2}{*}{$\mathrm{t}$} & \multirow[b]{2}{*}{ Sig. } \\
\hline & B & Std. Error & Beta & & \\
\hline $1 \quad$ (Constant) & .267 & 1.049 & & .254 & .800 \\
\hline Kepemimpinan & .205 & .088 & .283 & 2.340 & .023 \\
\hline Kedisiplinan & .234 & .091 & .237 & 2.556 & .013 \\
\hline Motivasi & .296 & .074 & .444 & 4.018 & .000 \\
\hline
\end{tabular}

a. Dependent Variable: Kinerja

According to the table 1 the results of multiple linear regression analysis, the regression equation can be obtained as follows:

$$
\mathrm{Y}=0,267+0,205 \mathrm{X}_{1}+0,234 \mathrm{X}_{2}+
$$

$\mathrm{T}$ tests were used in this research is using criteria with a significance level of $5 \%$, and if $t_{\text {count }}>t_{\text {table, then the }}$ hypothesis is accepted and if $t_{\text {count }}$

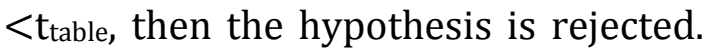
$\mathrm{T}$ test results in this study can be seen in table 1 above.
Hypothesis 1: Leadership significant effect on performance.

$\mathrm{T}$ test results on leadership variable $\left(\mathrm{X}_{1}\right)$ obtained $\mathrm{t}_{\text {count }}=2.340$ with 0.023 significance. By using a significance limit of $5 \%$ or 0.05 obtained ttableof 1.669. This means that the tcount $(2.340)>$ table (1.669), which means that the first hypothesis is accepted. With a significance level of 0.023 which is below the 0.05 limit, it can be concluded that the leadership has a significant influence on 
performance.

Hypothesis 2: Discipline significant effect on performance.

$\mathrm{T}$ test results on variable discipline $\left(\mathrm{X}_{2}\right)$ obtained $\mathrm{t}_{\text {count }}=2.556$ with 0.013 significance. By using a significance limit of $5 \%$ or 0.05 obtained table of 1.669. This means that the $t_{\text {count }}$ (2.556) $>$ ttable (1.669), which means that the second hypothesis is accepted. With a significance level of 0.013 which is below the 0.05 limit, it can be concluded that the discipline has a significant influence on performance. Hypothesis 3: Motivation significant effect on performance.

$\mathrm{T}$ test results on the motivation variable $\left(\mathrm{X}_{3}\right)$ obtained $\mathrm{t}_{\text {count }}=4.018$ with 0.000 significance. By using a significance limit of $5 \%$ or 0.05 obtained ttable of 1.669. This means that the $t_{\text {count }}(4.018)>t_{\text {table }}(1.669)$, which means that the third hypothesis is accepted. With a significance level of 0.000 which is below the 0.05 limit, it can be concluded that motivation has a significant influence on performance.

Test dominant in this research by looking at the value of the largest beta. According to the table above $4: 10$, unknown variables that have the greatest beta value is the motivation variable with a beta value of 0.290 . This means that the fourth hypothesis is rejected, that leadership is not the dominant influence on performance.

The result of the calculation of the coefficient of determination $\left(\mathrm{R}^{2}\right)$ can be seen in table 2 as follows:

Table 2. Calculation of coefficient of determination $\left(R^{2}\right)$

Model Summaryb

\begin{tabular}{|l|r|r|r|r|}
\hline Model & R & R Square & \multicolumn{1}{|c|}{$\begin{array}{c}\text { Adjusted R } \\
\text { Square }\end{array}$} & Std. Error of the Estimate \\
\hline 1 & $.892^{\mathrm{a}}$ & .795 & .785 & 1.03175 \\
\hline
\end{tabular}

a. Predictors: (Constant), Motivasi, Kedisiplinan,

Kepemimpinan

b. Dependent Variable: Kinerja

According to the table 2 can be known coefficient of determination $\left(R^{2}\right)$ is approximately 0,795. This means that $79.5 \%$ of performance can be explained by the leadership, discipline and motivation. While the remaining $20.5 \%$ performance is influenced by other variables that are not researched in this study such as organizational culture, job satisfaction, commitment, and so on.

\section{INTERPRETATION}

1. Leadership significant effect on performance

Leaders through leadership style that is applied to the members will affect the performance of the member.
Leadership is required to create a good condition or state in order to provide incentives for members to be able to work with the maximum. Leadership accordance with the conditions and circumstances would create a good working climate. With the creation of a good working climate, the members will be eager to work. This will have a positive impact on performance. According to Hasibuan (2008), the leadership set by a leader within an organization to create a harmonious integration and encourage the morale of employees to achieve maximum goals. Leadership is the way a leader affects the behavior of subordinates, to 
cooperate and work productively to achieve organizational goals.

Hypothesis testing results show that the leadership of a significant effect on the performance of Member Lumajang Police Force Sabhara with a positive direction. Based on these test results, it can be concluded that the first hypothesis stating leadership significant effect on the performance of Member Lumajang Police Force Sabhara accepted. This means that if the perception Members Unit Sabhara Police Lumajang about the leadership of Chief Lumajang increases, it will improve the performance of Members Unit Sabhara Police Lumajang, and vice versa if the perception Members Unit Sabhara Police Lumajang about the leadership of Chief Lumajang decreases, it will degrade the performance of Members Unit Sabhara Police Lumajang.

The results of this study are consistent with the opinion of Hasibuan (2008) and the research conducted by Arief and Farid (2011), Hakim (2011), Riyadi (2011), and Fitriani, Nasir and Yunus (2015), which indicates that the leadership of positive significant effect on the performance. However, this study reject the research of Joseph (2010), which indicates that leadership has positive effect but not significant on performance.

Leadership has significant effect on the performance of Lumajang Police Unit SabharaMember. This was seen when the change of leadership or the Chief of Lumajang, it will also change the policies within the organization. The frequent change of leadership in Lumajang Police turned out to have a positive impact on its members, especially Lumajang Police Unit SabharaMember. Policy changes that brought the leadership and make a positive impact on Lumajang Police Unit Sabhara to be more advanced.

The Ratings on Lumajang PoliceUnit Sabhara Member leadership to the overall indicator showed that most respondents have a high perception (good) toward the leadership of Chief Lumajang they feel. The most important indicator of leadership is to press the importance of a relationship with fellow members. It gives a good effect, because by emphasis on establishing relationships with fellow members, then in order to resolve the problems or obstacles it can be overcome together.

\section{Discipline significant effect on performance}

The discipline has a positive impact on performance. In order to achieve maximum performance in an organization indispensable high work discipline of each member. Good discipline necessarily reflect the responsibility of each member of the tasks assigned to him. Members said to have high discipline if it has a consistent, consistent, responsibility for the tasks entrusted. According to Hasibuan (2005), discipline is the operative functions of human resource management which is important because the better discipline of employees, the higher the performance that can be achieved.

Hypothesis testing results indicate that disciplinary significant effect on the performance of Lumajang Police Unit Sabhara Member with a positive direction. Based on these test results, it can be concluded that the second hypothesis which states disciplinary significant effect on the performance of Lumajang Police Unit Sabhara Member accepted. This means that if the perception Lumajang Police Unit 
Sabhara Member about discipline increases, it will improve the performance of Lumajang Police Unit Sabhara Member, and vice versa if the perception ofLumajang Police Unit Sabhara Member about discipline declines, it will degrade the performance of Lumajang Police Unit Sabhara Member.

The results of this research is in line with the opinion of Hasibuan (2005) and research conducted by Arief and Farid (2011), and Rahayu and Idrus (2015), which concluded that disciplinary gives the positive and significant effect on performance. However, this study reject the results Hetami (2008), which concluded that the discipline has a negative effect but significant on performance.

Based on an assessment of Lumajang Police Force Sabhara Member to the overall of discipline indicator, the results showed that most respondents have a high perception of the discipline that they have felt. From the results of the indicators saying that members adhere to the applicable rules and members always obey the rules of society in charge is the cornerstone of Lumajang Police Unit SabharaMember. It is not only Lumajang Police Unit SabharaMember which should adhere to applicable regulations, but also to all other members of the police.It is likely becomes a positive impact on the assessment of performance. In addition, Members of Lumajang Police Unit Sabhara are always side by side and close to the people, so that the members in charge must always obey the rules that exist in society. This is to facilitate communication with the public, especially when there is a problem it can be resolved soon.

\section{Motivation significant effect on performance}

Motivation is closely related to performance. Motivating members is the main task of a leader. It is intended by motivating his members, their power incentive of each member to work is maximum. Members who are motivated of working can be seen from the responsibility to work, whether it can be completed with the maximum of what less than the maximum. According to Sedarmayanti (2008), motivation is the emergence of behaviors that lead to a particular destination with a full commitment to achieve the intended purpose. Applying motivation approach means leaders create a condition that can make members feel motivated. Members should be inspired to feel their expectations and availability in the organization where he works. In most cases, the motivation of an individual will arise due to the influence of an effective leader. So the effectiveness of leadership will look how to motivate their members effectively.

Hypothesis testing results showed that motivation significantly influence the performance of Lumajang Police Unit Sabhara Member with a positive direction. Based on these test results, it can be concluded that the third hypothesis stating motivation significant effect on the performance of Lumajang Police Unit Sabhara Member is accepted. This means that if the perception of Lumajang Police Unit Sabhara Member about motivation increases, it will improve the performance of Lumajang Police Unit Sabhara Member, and vice versa if the perception of Lumajang Police Unit Sabhara Member about motivation decreases, it will degrade the 
performance of Lumajang Police Unit Sabhara Member.

The results are in line with the opinion of Sedarmayanti (2008) and the research conducted by Hetami (2008), Riyadi (2011), and Fitriani, Nasir and Yunus (2015), concluded that the motivation positive significant effect on performance. But it does not support research conducted by Joseph (2010), that say the motivation has negative effect and no significant toward performance. This study also does not support the research of Hakim (2011), that concluded motivation does not significantly influence to performance.

From the assessment results of Lumajang Police Unit Sabhara Member to all indicators of motivation, it turns out most members give a high evaluation. Facts show that the members do this work because of the encouragement of the family which is the cornerstone for Lumajang Police Unit SabharaMember. It is indeed most of Lumajang Police Unit SabharaMember got a boost from the family when they became a member of the police. On average they become members of the police because of the encouragement of families who were members of the police as well. But this would have a positive effect on their performance.

\section{Leadership is the dominant influence on performance}

Leadership is important in an organization where the leader makes an important contribution to its members. Besides leaders also have authority in decision-making. According to Siagian in Sedarmayanti (2008), leadership is a core management because leadership is the driving force for human resources and other natural resources.
The results showed that the leadership is not the dominant influence on the performance of Lumajang Police Unit SabharaMember. Variables that dominantly influence on performance is the motivation. This study rejects the notion of Sedarmayanti (2008) and research of Arief and Farid (2011), which proves that the leadership has dominant influence on performance.

The interesting thing about motivation of Lumajang Police Unit Sabhara Members if is is seen on the level of education is largely educated to degree (S1). Their high motivation of members who have a high level of education is very influential on performance. When running errands it can be seen there are some members who fast in implementing the tasks and are motivated to complete the task immediately. Indeed several members of the high educational level factors also affect the performance of Lumajang Police Unit Sabhara Member.

The age factor is also has a positive impact on the performance where the age more members is between 31 to 35 years old and there are over than 35 years old. At such age, the emotional high is no longer visible when compared with ages between 26 and 30 years. Some members do have an emotional feeling when carrying out the duties will not affect either the performance and also the motivation is less. At the age of 31 to 35 years old and over 35 years, they've been motivated to devote themselves. Their high motivation in the ages which also impacts their performance.

Motivation is dominantly influence on the performance of Lumajang Police Force SabharaMember. Motivation is more influence on the performance compared to the leadership because 
Lumajang Police Force Sabhara Member are already demonstrated their high motivation both from inside and from outside of theythemselves. Leadership is used to be the factors that influence on the performance, for their authoritarian leadership in every military unit. However, after the change of regulation time, the original authoritarian leadership is now no longer exists. This is what makes one of the factors of leadership influence is not greater than the motivation of members.

\section{CONCLUSION}

Based on the analysis and interpretation of data, it can be concluded as follows:

1. Leadership has significant effect on the performance of the positive direction.

2. Discipline has significant effect on the performance of the positive direction.

3. Motivation has significant effect on the performance of the positive direction.

4. Motivation is dominantly influence on performance.

\section{IMPLICATION}

This study refuses the theory and research that states the leadership is dominantly influence on performance, while in this study the dominant effect is motivation.

The end result of this research is to improve the performance, then the leadership, discipline and motivation should be enhanced. This is consistent with the concept of human resources.

\section{REFERENCES}

Abdillah, Chaidir, Arief dan Wajdi, Farid. 2011. Pengaruh Kepemimpinan, Stres Kerja,
Disiplin Kerja dan Kompensasi dengan Kinerja Pegawai. Jurnal Ekonomi Manajemen Sumber Daya. Vol. 12, No. 1, Juni 2011.

Fitriani, Azis Nasir dan Yunus Muklis. 2015. Pengaruh Gaya Kepemimpinan, Motivasi dan Lingkungan Kerja terhadap Kinerja Pegawai dan dampaknya pada Kinerja Dinas Kesehatan Kabupaten Bireuen. Jurnal Manajemen Pascasarjana Universitas Syiah Kuala ISSN 2302-0199, Vol. 4 No. 3, Agustus 2015:92-100.

Hakim, Lukmanul. 2011. Pengaruh Gaya Kepemimpinan terhadap Kinerja Pegawai Negeri Sipil melalui Motivasi pada Dinas Perhubungan Kota Palembang. ILMIAH Vol. III, No. 3. 2011.

Hasibuan, Malayu S P. 2005. Manajemen Prestasi Kerja. Jakarta: Rajawali.

2008.

Manajemen Sumber Daya Manusia. Jakarta: PT. Bumi Aksara.

Hetami, Aditeya Arie. 2008. Pengaruh Motivasi, Kemampuan dan Disiplin terhadap Kinerja Karyawan pada Sebuah Persero Asuransi. Jurnal Ekonomi dan Bisnis 6 (2): 66-81.

Istijanto. 2010. Riset Sumber Daya Manusia. Jakarta: PT Gramedia Pustaka Utama.

Mangkunegara, Prabu Anwar. 2001. Perilaku dan Budaya Organisasi. Bandung: PT Refika Aditama.

Rivai, Veithzal. 2008. Kepemimpinan dan Perilaku Organisasi. Edisi Kedua. Jakarta: PT RajaGrafindo Persada.

Riyadi, Slamet. 2011. Pengaruh Kompensasi Finansial, Gaya Kepemimpinan dan Motivasi 
Kerja terhadap Kinerja

Karyawan pada Perusahaan

Manufaktur di Jawa Timur.

Jurnal Manajemen dan

Kewirausahaan, Vol. 13, No. 1, Maret 2011:40-45.

Sedarmayanti. 2008. Manajemen Sumber Daya Manusia,

Reformasi Birokrasi dan

Manajemen pegawai Negeri

Sipil. Bandung: PT Refika Aditama.

Suci, Puji, Rahayu dan Idrus, Syafi'i, Mohamad. 2015. The Influence of Employee Training and Discipline Work against
Employee Performance PT. Merpati Nusantara Airlines (Persero). ISSN 1918-7173, EISSN 1918-7181. Review of European Studies; Vol. 7, No. $11 ; 2015$.

Yusuf, $\quad 2010$. Kepemimpinan, Motivasi dan Kepuasan Kerja terhadap Kinerja Pegawai pada Kantor Bersama Sistem Administrasi Manuggal Satu Atap (Samsat) Kota Batam. Tesis Program Pascasarjana Magister Manajemen. Universitas Terbuka.

\section{BIOGRAPHY}

Marsuhin, born in Lumajang on September 4, 1986. I started my education at SDN 02 Dadapan graduated in 1998. I continue to SMPN 02 Gucialit graduated in 2001. Then followed SMKN Tekung graduated in 2004.

I started a career as a Member Sabhara Lumajang Police in 2005 and at the same time continuing education at the University of Lumajang S1 graduated in 2010 majoring in legal studies. Because there my interest in the field of business, then I took a course in S1 at STIE Widya Gama Lumajang graduated in 2014 majoring in management. Then proceeded S2 at STIE Mandala Jember master of management majors. Now I am placed in the planning of Lumajang Police. 